\title{
BEHAVIOURS AND ATTITUDES ABOUT BODY IMAGE AND EATING DISORDERS AMONG ADOLESCENT FEMALES IN KRAGUJEVAC
}

\author{
Maja Jovanovic
}

Department of Biotechnology, Faculty of Medical Sciences, University of Kragujevac, Kragujevac, Serbia

\author{
PONAŠANJE I STAVOVI O TELESNOM IZGLEDU I POREMEĆAJI \\ ISHRANE KOD ADOLESCENTKINJA \\ U KRAGUJEVCU \\ Maja Jovanović \\ Katedra za biotehnologiju, Fakultet medicinskih nauka, Univerzitet u Kragujevcu, Kragujevac, Srbija
}

\begin{abstract}
Eating disorders are often in older teens and young women with prevalence 4-5\% with increasing tendency. The aim of this study was to investigate the prevalence of eating disorders among adolescents in the city of Kragujevac, and to examine the relationship between the age and the type of eating disorder that can occur in adolescents.

This descriptive, cross sectional study involved 220 participants (16-25 years old, 105 high school students and 115 students of the Faculty of Medical Sciences in Kragujevac, Serbia). Eating Attitudes Test EAT-26 questionnaire was used as a screening instrument, which consists of three subscales related to eating disorders (dieting, bulimia, oral control diet). The frequency of disturbed attitudes and eating habits among the investigated population was $26,8 \%$ (EAT-26 score $\geq 20$ ). The high school students had a significantly higher score values (30,4\% of girls achieved values EAT-26 score $\geq 20)$ than the medical students. Among the respondents, 17,6\% were malnourished, 72,7\% normal weight, 9,3\% of the overweight and 0,5\% obese. Eating disorder not otherwise specified (EDNOS) was $13,7 \%$, subclinical bulimia $4,4 \%$ and subclinical anorexia $8,8 \%$. There was statistically significant difference $(p=0,024)$ in the expression of behavioral disorders between students of high school and faculty education.

Our results suggest that malnutrition and anorexic syndrome are more frequently in population of medical students, but on the other hand, obesity and subclinical bulimic syndrome have a higher prevalence in high school student's population, which can be explained by inappropriate education for adolescents.
\end{abstract}

Keywords: eating disorders, adolescents, EAT-26.

\section{SAŽETAK}

Poremećaji ishrane su uobičajeni kod starijih tinejdžerki i mladih žena sa prevalencom od 4-5\% koja ima tendenciju rasta. Cilj ovog istraživanja je bio da se ispita učestalost poremećaja u ishrani među adolescentkinjama u gradu Kragujevcu, $i$ da se ispita povezanost između starosti i vrste poremećaja ishrane koji se može javiti kod adolescentkinja.

Ova deskriptivna, studija preseka, je obuhvatila 220 ispitanica (starosti 16-25 godina, 105 srednjoškolki i 115 studentkinja Fakulteta medicinskih nauka u Kragujevcu, u Srbiji). Upitnik o stavovima u ishrani, EAT-26 je korišćen kao skrining instrument, koji se sastoji od tri subskale o poremećajima ishrane (dijeta, bulimija, oralna kontrola ishrane). Učestalost poremećenih stavova $i$ navika u ishrani u ispitivanoj populaciji je bila 26,8\% (EAT-26 skor $\geq 20$ ). Učenice srednjih škola imale su statistički značajno više vrednosti EAT-26 skora od studentkinja medicine. Među ispitanicama njih $17,6 \%$ su bile pothranjene, 72,7\% normalne težine, 9,3\% prekomerno uhranjene i 0,5\% gojazne. Poremećaj ishrane koji nije drugačije definisan je bio zastupljen u 13,7\%, subklinička bulimija 4,4\% i subklinička anoreksija 8,8\%. Postojala je statistički značajna razlika $(r=0,024)$ između srednjoškolki i studentkinja medicine u ispoljavanju ovih poremećaja u ishrani.

Naši rezultati pokazuju da su neuhranjenost i subklinički anoreksični sindrom češći u populaciji studentkinja medicine, a da sa druge strane gojaznost i subklinički bulimični sindrom imaju veću učestalost u populaciji srednjoškolki, što se može donekle objasniti neodgovarajućim obrazovanjem adolescenata.

Ključne reči: poremećaji ishrane, adolescenti, EAT-26.

\section{ABBREVIATIONS}

EDNOS-Eating disorder not otherwise specified BED-Binge eating disorder EAT-26-Eating Attitudes Test EAT-26

BMI-Body Mass Index

D-Dieting

B-Bulimia

O-Oral control diet
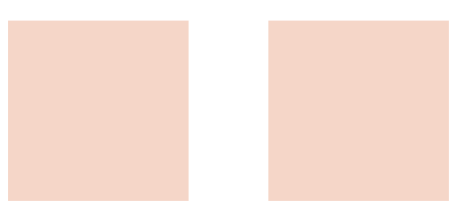


\section{INTRODUCTION}

Proper nutrition is an essential precondition for a healthy life and is the basis for proper growth and development, physical and mental status, the defensive ability of the organism and the operation of all vital functions (1). Disordered attitudes and behaviours concerning food intake are frequent in adolescents, with a prevalence of 4-5\%, and a ratio of 6:1 to 10:1 in favour of females. Research has shown an increase in the prevalence of these disorders, which are characterized by excessive concern about body shape and weight, followed by distorted attitudes and inappropriate, irregular or chaotic food intake (2).

The lifelong prevalence of anorexia in women ranges from $0.9 \%$ to $2.2 \%$, whereas the frequency of bulimia in women is $1.5-2 \%$. However, these eating disorders occur most often in adolescence, during which the prevalence may reach as high as $5 \%$. The prevalence of binge eating disorders ranges from $3.5 \%$ to $10 \%$ in the general population $(3,4)$. However, the most common eating disorders, either in clinical samples or in the general population, are other categories, which are defined as eating disorders not otherwise defined (EDNOS) (5). EDNOS is a heterogeneous group of disorders, which is not very well defined, and includes partial syndromes of anorexia, bulimia, purging and overeating - binge eating disorder (BED) $(2,6)$. The prevalence of BED ranges from 0.7-4\% in the normal population. The use of strict criteria for the diagnosis of eating disorders can hinder recognition of these disorders and their subclinical forms at an early stage. Disordered eating habits have a significant impact on health, even in the absence of complete formal criteria for eating disorders (7).

The aim of this study was to investigate the prevalence of eating disorders among adolescents in the city of Kragujevac, Serbia. Additionally, the nutritional statuses of and the relationship between age and the types of eating disorders noted among adolescents were investigated.

\section{MATERIALS AND METHODS}

This descriptive, cross sectional study was conducted in March and April, 2013. The sample consisted of 220 adolescents aged 16 to 25 years. The study was conducted in four secondary schools (gymnasium, medical, economic, and technical schools) and the Faculty of Medical Science, University of Kragujevac. The study population consisted of two groups, one of which consisted of 105 high school students, and the other of 115 medical students. Respondents were selected using simple random sampling. Inclusion criteria were as follows: female gender and age between 16 and 25 years. Exclusion criteria were as follows: pregnancy, lactation, diabetes, and previous diagnosis of an eating disorder.

The survey used the Eating Attitudes Test EAT-26 questionnaire (8). The questionnaire refers to satisfaction with body image and body weight, as well as attitudes and

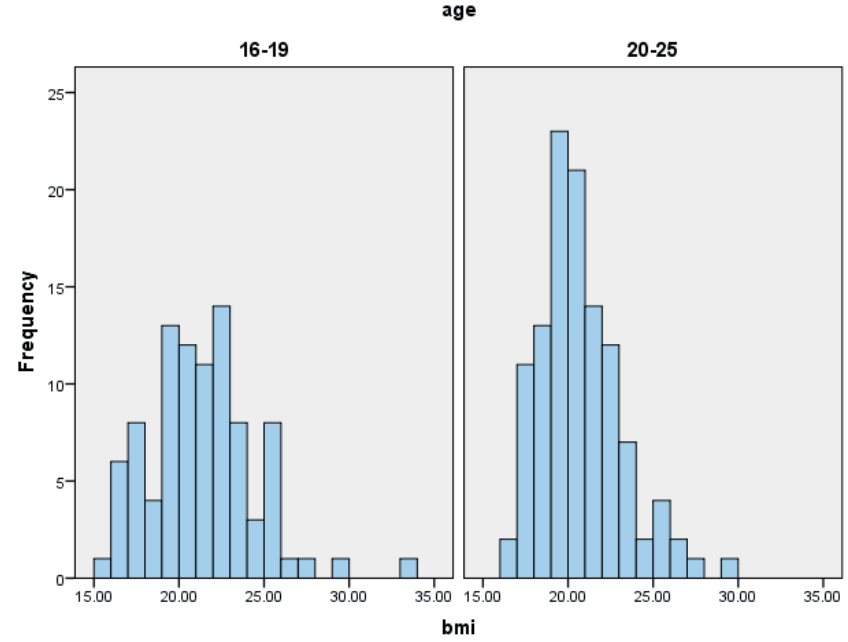

Figure 1. Frequency distribution of BMI by age group

behaviours towards food and body. The total EAT-26 score is derived as the sum of composite items and ranges from 0 to 78. Answers were graded on a scale of six points from always to never, with 3 points awarded for a response of "always", 2 points for "usually", 1 point for "often", and 0 points for answers pertaining to "rarely", "sometimes", and "never". Results of $\geq 20$ points, with at least one positive response in the behavioural part, are associated with abnormal eating attitudes and behaviour and can be identified as an eating disorder. The EAT-26 is distributed in three subscales as follows: Factor 1-D (diet), Factor 2-B (bulimia), Factor 3-O (oral control diet); this distribution allows researchers to obtain more information from the same survey. Factor 1-D determines whether respondents have a distorted image of their body, whether they are burdened with dieting and a desire to be thinner, and whether they need to constantly eat diet food. Factor 2-B determines the inability to stop overeating, which is often followed by vomiting and use of laxatives and diuretics. Factor 3-O determines the existence of self-control in eating and maintaining a low body weight, which is often associated with obsessive-compulsive behaviour. Respondents with high EAT-26 scores in this area are prone to anorexia (8).

The software package IBM SPSS Statistics 20 was used for determining the measures of central tendency and variability using descriptive statistics methods. To determine dependence between variables, the chi-square test was used. To determine differences between two groups, Student's t-test for independent samples and the MannWhitney U test were used. All statistical analyses were performed with confidence intervals of $95 \%$.

\section{RESULTS}

The study comprised 205 persons aged 16 to 25 years (average age $20.67 \pm 2.94$ years). The mean body weight was $60.05 \pm 8.557 \mathrm{~kg}$, whereas the mean desired body weight was $57.8 \pm 6.271 \mathrm{~kg}$. The mean BMI for high school 
Table 1. Percentage of respondents according to BMI and limit value EAT-26 scores

\begin{tabular}{|c|c|c|c|c|c|c|c|c|c|c|}
\hline \multirow{3}{*}{ Score } & \multicolumn{8}{|c|}{ Body Mass Index - BMI $\left(\mathbf{k g} / \mathrm{m}^{2}\right)$} & \multirow{3}{*}{$\chi^{2}$} & \multirow{3}{*}{$\mathbf{p}$} \\
\hline & \multicolumn{2}{|c|}{$<18.5$} & \multicolumn{2}{|c|}{$18.5-24.9$} & \multicolumn{2}{|c|}{ 25.0-29.9 } & \multicolumn{2}{|c|}{$>30$} & & \\
\hline & $\mathbf{n}$ & $\%$ & $\mathbf{n}$ & $\%$ & $\mathbf{n}$ & $\%$ & $\mathbf{n}$ & $\%$ & & \\
\hline $0-19$ & 21 & 14.0 & 113 & 75.3 & 15 & 10.0 & 1 & 0.7 & \multirow{3}{*}{5.267} & \multirow{3}{*}{0.153} \\
\hline $20-78$ & 15 & 27.3 & 36 & 65.5 & 4 & 7.3 & 0 & 0 & & \\
\hline Total & 36 & 17.6 & 149 & 72.7 & 19 & 9.3 & 1 & 0.5 & & \\
\hline
\end{tabular}

$\mathrm{X}^{2}$ - value of chi-square test $\mathrm{p}$ value

students was $21.29 \pm 3.022 \mathrm{~kg} / \mathrm{m} 2$. The mean BMI for medical students was $20.76 \pm 2.409 \mathrm{~kg} / \mathrm{m} 2$ (Figure 1 ).

Malnutrition was most common in persons with eating disorders (Table 1).

Subclinical bulimia was significantly more common in high school girls than in medical students $(\mathrm{p}=0.024)$, whereas subclinical anorexia was more common in medical students $(\mathrm{p}=0.024)$ (Table 2).

Most persons with eating disorders showed significant behaviour disorders of food intake (Table 3).

Children of divorced parents and children unsatisfied by their socioeconomic statuses more commonly exhibited signs of eating disorders (Fig. 2).

\section{DISCUSSION}

Because our research was conducted in a healthy young population, we did not expect such a large percentage of persons to meet the criteria for malnutrition. This result may be explained by the fact that our population was from an urban area, whereas studies that investigated either a larger part of our country (Vojvodina) (10) or Serbia in its entirety (11) showed much lower incidences of malnutrition. A possible explanation is that girls from more urban areas tend to have the lowest possible weights and are significantly more likely to develop an eating disorder than girls from rural areas, as shown earlier (12).

Table 2. Numerical and percentage representation of factors $(\mathrm{D}, \mathrm{B}, \mathrm{O})$ by age group

\begin{tabular}{|c|c|c|c|c|c|c|c|c|}
\hline & \multicolumn{2}{|c|}{ D } & \multicolumn{2}{|c|}{ B } & \multicolumn{2}{|c|}{$\mathbf{O}$} & \multirow{2}{*}{$\chi^{2}$} & \multirow{2}{*}{$\mathbf{p}$} \\
\hline & $\mathbf{n}$ & $\%$ & $\mathbf{n}$ & $\%$ & $\mathbf{n}$ & $\%$ & & \\
\hline High school girls & 14 & 15.2 & 8 & 8,7 & 6 & 6.5 & \multirow{2}{*}{7.429} & \multirow{2}{*}{0.024} \\
\hline Medical students & 14 & 12.4 & 1 & 0,9 & 12 & 10.6 & & \\
\hline Total & 28 & 13.7 & 9 & 4,4 & 18 & 8.8 & & \\
\hline
\end{tabular}

$\mathrm{X}^{2}$ - value of chi-square test

$\mathrm{p}$ value

Table 3. Percentage of responses to questions from a group of behavioural disorders, by EAT-26 scores

\begin{tabular}{|c|c|c|c|c|c|}
\hline Variables & Answers & Score $\leq 19$ & Score $\geq 20$ & $x^{2}$ & $\mathbf{p}$ \\
\hline \multirow{2}{*}{ Overeating* } & Never & 92.0 & 58.2 & \multirow{2}{*}{30.163} & \multirow{2}{*}{0.000} \\
\hline & Several times a month & 8.0 & 41.8 & & \\
\hline \multirow{2}{*}{ Vomit } & Never & 97.3 & 87.3 & \multirow{2}{*}{6.163} & \multirow{2}{*}{0.013} \\
\hline & Several times a month & 2.7 & 12.7 & & \\
\hline \multirow{2}{*}{ Purgatives } & Never & 94.7 & 83.6 & \multirow{2}{*}{5.070} & \multirow{2}{*}{0.024} \\
\hline & Several times a month & 5.3 & 16.4 & & \\
\hline \multirow{2}{*}{ Exercise $^{* *}$} & Never & 63.8 & 41.8 & \multirow{2}{*}{7.056} & \multirow{2}{*}{0.008} \\
\hline & Several times a month & 36.2 & 58.2 & & \\
\hline \multirow{2}{*}{ Weight loss ${ }^{* * *}$} & Yes & 14.7 & 27.3 & \multirow{2}{*}{3.513} & \multirow{2}{*}{0.061} \\
\hline & No & 85.3 & 72.7 & & \\
\hline
\end{tabular}

* Uncontrolled food intake

** Exercise lasting longer than 60 minutes a day and goal of weight loss or weight control

*** Weight loss of $9 \mathrm{~kg}$ or more in the last 6 months 

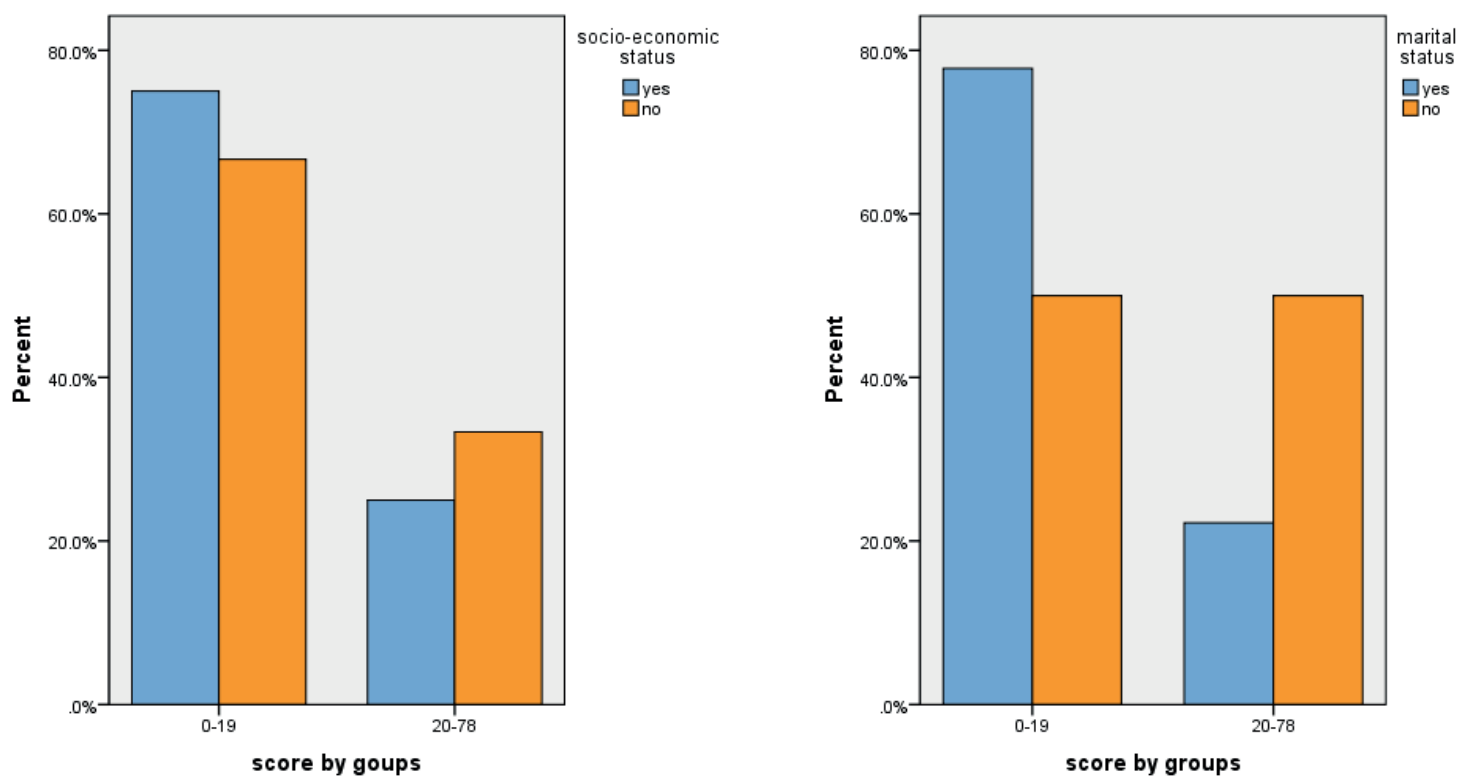

Figure 2. Satisfaction with socio-economic status or marital status of parents by EAT-26 scores

Another unexpected result was the surprisingly low representation of overweight girls in our sample compared with the numbers of girls in earlier surveys in Serbia (10, 11). It is a well-known fact that the number of overweight persons is steadily growing; therefore, the surprisingly small number of overweight girls in our study may have been due to the chronic desire of young urban girls to be thin. It should be taken into consideration that our respondents themselves gave information about their body weights and heights, and it is possible that they deliberately reduced their weights. If that were the case, it would give us important information about the desirability of thinness among young women today. More than half of the respondents indicated that they would like to lose weight, although they were not actually overweight. Research conducted on high school girls in Banja Luka showed fewer obese and underweight girls compared with our study (13), and even lower values were obtained in some European countries (14-17). The result that even $30.4 \%$ of our girls achieved EAT-26 scores over 20 is very worrisome because it puts Serbia among the countries with the highest prevalences of eating disorders (9). It is known that eating habits within our nation are significantly different from those in countries such as Japan and China, which have a significantly lower incidences of eating disorders than other parts of the world. Although the prevalences of eating disorders have grown in those countries for years, they are still far lower than the prevalence of eating disorders in our country (18-20).

Eating disorders have devastating physical, psychological and social consequences. This is reflected in high levels of mortality, morbidity and poor quality of life. The mortality rate for subclinical eating disorders is 3.31 deaths per 1,000 people per year (21). It is known that only 4-6\% of individuals with eating disorders receive professional medical help (22).
We think that our results suggest the need for screening for eating disorders, which would allow for the early identification of eating disorders. Screening may be useful for general practitioners in identifying persons for earlier treatment, which has been proven to lead to more favourable outcomes.

\section{ACKNOWLEDGEMENTS}

I thank Professor Vuckovic-Dekic Ljiljana for her comments and support.

In addition, I thank the authorities of the high schools and the Faculty of Medical Sciences, who allowed this research to be conducted, and the surveyed respondents for their cooperation.

\section{REFERENCES}

1. Novaković B, Mirosavljev M, Jevtić M. Higijena ishrane, Novi Sad, Medicinski fakultet, 2005.

2. Dalle Grave R, Calugi S. Eating disorder not otherwise specified in an inpatient unit: the impact of altering the DSM-IV criteria for anorexia and bulimia nervosa. Eur Eat Disord Rev. 2007;15 (5):340-9. Available at:

http://onlinelibrary.wiley.com/doi/10.1002/erv.805/abst ract;jsessionid=0706DD6772F64F3A41FE88BEA24D AB58.d01t02/ Last visited: 12.04.2013.

3. Franco KN.Eating Disorders, 2010 Available at: http:// www.clevelandclinicmeded.com/medicalpubs/diseasemanagement/psychiatry-psychology/eating-disorders/ Last visited: 12.04.2013.

4. American Psychiatric Association (APA). Diagnostic and Statistical Manual of Mental Disorders. (4th ed ) (DSM-IV). Washington DC: American Psychiatric As- 
sociation; 2000 Available at: http://www.psychiatry. org/practice/dsm/ Last visited: 05.03.2013.

5. Thomas JJ, Vartanian LR, Brownell KD. The relationship between eating disorder not otherwise specified (EDNOS) and officially recognized eating disorders: Meta-analysis and implications for DSM. Psychol Bull. 2009;135(3):407-33. Available at: http://www.ncbi.nlm. nih.gov/pmc/articles/PMC2847852/pdf/nihms171851. pdf/ Last visited: 20.04.2013.

6. Herpertz-Dahlmann B, Hagenah U, Vloet T, Holtkamp K. Adolescent eating disorders. Prax Kinderpsychol Kinderpsychiatr. 2005 Apr;54(4):248-67. Available at: http://www.ncbi.nlm.nih.gov/pubmed/15918539/ Last visited: 20.04.2013.

7. Bravender T, Bryant-Waugh R, Herzog D, Katzman D, Kriepe RD, Lask B et al. (2010), Classification of eating disturbance in children and adolescents: Proposed changes for the DSM-V. Eur. Eat. Disorders Rev., 18: 79-89. Available at: http://onlinelibrary.wiley.com/ doi/10.1002/erv.994/abstract;jsessionid=300E0D6771 A91D340D79FD262343FEEE.f02t01?deniedAccessC ustomisedMessage $=$ \&userIsAuthenticated $=$ false Last visited: 15. 03.2013.

8. The EAT-26 has been reproduced with permission. Garner et al. (1982). The Eating Attitudes Test: Psychometric features and clinical correlates. Psychological Medicine, 12, 871-8. Available at: http://www.eat-26. com/permission.php/ Last visited: 05.03.2013.

9. B Orbitello, R Ciano, M Corsaro, PL Rocco, C Taboga, L Tonutti, M Armellini, M Balestrieri, The EAT26 as screening instrument for clinical nutrition unit attenders, International Journal of Obesity (2006) 30, 977-981. Available at: http://www.nature.com/ ijo/journal/v30/n6/abs/0803238a.html/ Last visited: 15.05.2013.

10. Novosadski Edukativni Centar, Akcija u toku-Projekat o informisanju mladih o poremećajima ishrane, Available at: http://nec.rs/2012/06/17/akcija-u-toku/ Last visited: 12.06 .2013 .

11. Ministarstvo zdravlja Republike Srbije. Istraživanje zdravlja stanovnika Republike Srbije, 2006. godina. Osnovni rezultati. Ministarstvo zdravlja Republike Srbije; Beograd, 2007; 40; 43-4 Available at:

http://www.zdravlje.gov.rs/downloads/Zakoni/Ostalo/ Zdravlje\%20stanovnika\%20Srbije\%20-\%20Batut.pdf/ Last visited: 15.05.2013.

12. Bilali A, Galanis P, Velonakis E, Katostaraset T. Factors associated with abnormal eating attitudes among Greek adolescents. Journal of Nutrition Education and Behaviour 42.5 (2010): 292-8. Available at: http://www.sciencedirect.com/science/article/pii/S1499404609002887/ Last visited: 20.04.2013.

13. Radmanović-Burgić M, Gavrić Ž, Štrkić D. Učestalost poremećaja ishrane kod adolescentkinja. Aktuelnosti iz neurologije, psihijatrije i graničnih područja, 2008;16(1-2):7-13. Available at: http://scindeks.ceon.
rs/article.aspx?artid=0354-27260802007R/ Last visited: 20.04.2013

14. Neumarker KJ, Bettle N, Bettle O, Dudeck U, Neumarker U. The Eating Attitudes Test: comparative analysis of female and male students at the Public Ballet School of Berlin. Eur Child Adolesc Psychiatry. 1998;7:19-23. Available at:

http://www.ncbi.nlm.nih.gov/pubmed/9563809/ Last visited: 20.04.2013.

15. Buddeberg-Fischer B, Bernet R, Sieber M, Schmid J, Buddeberg C. Epidemiology of eating behaviour and weight distribution in 14 to 19 -year-old Swiss students. Acta Psychiatr Scand. 1996;93:296-304. Available at: http://www.ncbi.nlm.nih.gov/pubmed/8712031/ Last visited: 12.04.2013.

16. Wlodarczyk-Bisaga K, Dolan B. A two-stage epidemiological study of abnormal eating attitudes and their prospective risk factors in Polish schoolgirls. Psychol Med. 1996;26:1021-1032. Available at: http://www.ncbi.nlm. nih.gov/pubmed/8878334/ Last visited: 12.04.2013.

17. Ballester Ferrando D, De Gracia Blanco M, Patino Maso J, Sunol Gurnes C, Ferrer Avelli M. Eating attitudes and body satisfaction in adolescents: a prevalence study. Actas Esp Psiquiatr. 2002;30:207-212. Available at:

http://www.ncbi.nlm.nih.gov/pubmed/12217269/ Last visited: 12.04.2013.

18. Nakamura K, Hoshino Y, Watanabe A, et al. Eating problems in female Japanese high school students: a prevalence study. Int J Eat Disord. 1999;26:91-95. Available at: http://www.ncbi.nlm.nih.gov/pubmed/10349589/ Last visited: 12.04.2013.

19. Nishizawa Y, Kida K, Nishizawa K, Hashiba S, Saito K, Mita R. Perception of self-physique and eating behaviour of high school students in Japan. Psychiatry Clin Neurosci. 2003;57:189-196. Available at: http://www. ncbi.nlm.nih.gov/pubmed/12667166/

Last visited: 12.04.2013.

20. Lee S, Lee AM. Disordered eating in three communities of China: a comparative study of female high school students in Hong Kong, Shenzhen, and rural hunan. Int J Eat Disord. 2000 Apr;27(3):317-27 Available at: http:// www.ncbi.nlm.nih.gov/pubmed/10694718/ Last visited: 12.04 .2013

21. Frédérique RE Smink, Daphne van Hoeken, Hans W. Hoek. Epidemiology of Eating Disorders: Incidence, Prevalence and Mortality Rates. Curr Psychiatry Rep. 2012;14(4): 406-414. Published online 2012 May 27. Available at: http://www.ncbi.nlm.nih.gov/pmc/ articles/PMC3409365/ Last visited: 20.04.2013.

22. Jennifer M Jones, Susan Bennett Marion P, Olmsted Margaret L, Lawson, Gary Rodin. Disordered eating attitudes and behaviours in teenaged girls: a school based study, CMAJ 2001;165(5):547-52. Available at: http://www.cmaj.ca/content/165/5/547.short?relatedurls $=$ yes\&legid $=$ cmaj; $165 / 5 / 547 /$ Last visited: 20.04.2013. 